\title{
Blockade of airway inflammation and hyper-responsiveness by an angiopoietin-1 variant, COMP-Ang1
}

\author{
Kyung Sun Lee ${ }^{1 *}$, Ka Young Lee ${ }^{1 *}$, So Ri Kim", \\ Hee Sun Park', Seoung Ju Park', Kyung Hoon Min', \\ Chung-Hyun $\mathrm{Cho}^{3}$, Gou Young Koh ${ }^{3}$, Ho Sung Park', \\ and Yong Chul Lee ${ }^{1,5}$ \\ ${ }^{1}$ Department of Internal Medicine \\ Airway Remodeling Laboratory \\ Chonbuk National University Medical School \\ Jeonju 561-180, Korea \\ ${ }^{2}$ Department of Internal Medicine \\ Chungnam National University Medical School \\ Daejeon 301-747, Korea \\ ${ }^{3}$ Biomedical Research Center and Department of Biological Sciences \\ Korea Advanced Institute of Science and Technology \\ Daejeon 305-701, Korea \\ ${ }^{4}$ Department of Pathology \\ Chonbuk National University Medical School \\ Jeonju 561-180, Korea \\ ${ }^{5}$ Corresponding author: Tel, 82-63-250-1664; \\ Fax, 82-63-254-1609; E-mail, leeyc@ chonbuk.ac.kr \\ *These authors contributed equally to this work.
}

Accepted 17 October 2007

Abbreviations: Ang1, angiopoietin-1; BAL, bronchoalveolar lavage; COMP, cartilage oligomeric matrix protein; EBD, Evans blue dye; ICAM, intercellular adhesion molecule; OVA, ovalbumin; PAS, periodic acid-Schiff; RL, airway resistance; Tie2, tyrosine kinase with immunoglobulin and epidermal growth factor homology domain 2; VCAM, vascular cell adhesion molecule

\begin{abstract}
Inflammation of the asthmatic airway is usually accompanied by increased vascular permeability and plasma exudation. Angiopoietin-1 (Ang1) has potential therapeutic applications in preventing vascular leakage. Recently, we developed a soluble, stable, and potent Ang1 variant, COMP-Ang1. COMP-Ang1 is more potent than native Ang1 in phosphorylating the tyrosine kinase with immunoglobulin and epidermal growth factor homology domain 2 receptor in lung endothelial cells. We have used a mouse model for allergic airway disease to determine effects of COMP-Ang1 on allergen-induced bronchial inflammation and airway hyper-responsiveness. These mice develop the following typical pathophysiological features of allergic air-
\end{abstract}

way disease in the lungs: increased numbers of inflammatory cells of the airways, airway hyper-responsiveness, increased levels of Th2 cell cytokines (IL-4, IL-5, and IL-13), adhesion molecules (intercellular adhesion molecule-1 and vascular cell adhesion molecule-1), and chemokines (eotaxin and RANTES), and increased vascular permeability. Intravenous administration of COMP-Ang1 reduced bronchial inflammation and airway hyper-responsiveness. In addition, the increased plasma extravasation in allergic airway disease was significantly reduced by the administration of COMP-Ang1. These results suggest that COMP-Ang1 attenuates airway inflammation and hyper-responsiveness, prevents vascular leakage, and may be used as a therapeutic agent in allergic airway disease.

Keywords: angiopoietin-1; asthma; capillary permeability; receptor, Tie-2

\section{Introduction}

Bronchial asthma is a chronic inflammatory disease of the airways that is characterized by airway remodeling, which is usually accompanied by increased vascular permeability, resulting in plasma exudation (Bousquet et al., 2000). Several studies have revealed prominent increases in vessel number, vessel size, vascular surface area, and vascular leakage and important correlations between these alterations and disease severity in asthma (Hoshino et al., 2001; Lee and Lee, 2001; Lee et al., 2002, 2004). Increased vascular permeability causes leakage of intravascular components, including plasma extravasation. Exudation of plasma proteins into the airways contributes to the airway obstruction and hyper- responsiveness (Van de Graaf et al., 1991; Lee et al., 2002).

Angiopoietin-1 (Ang1) has been identified as a secreted protein ligand of tyrosine kinase with Ig and epidermal growth factor homology domain 2 (Tie2) (Yancopoulos et al., 2000). Tie2 is a member of the receptor tyrosine kinase family and is expressed predominantly on vascular endothelial cells, early hematopoietic cells, and their embryonic precursors (Takakura et al., 2000; Jones et al., 2001). Ang1- and Tie2-deficient mice have similar 
phenotypes characterized by embryonic lethality with severe vascular remodeling defects, insufficient vessel stabilization, and perturbed vascular maturation (Sato et al., 1993; Suri et al., 1996). In addition, Ang1 can counteract VEGF-induced side effects (Thurston et al., 2000; Kim et al., 2001) while having an additive effect on vessel formation (Chae et al., 2000; Thurston et al., 2000). These observations have suggested that Ang1 has potential therapeutic applications in inducing angiogenesis, enhancing endothelial cell survival, and preventing vascular leakage. However, production of Ang1 is hindered by aggregation and insolubility resulting from disulfide-linked higher-order structures. Recently, we have developed a soluble, stable, and potent Ang1 variant, COMP-Ang1 (Cho et al., 2004a, b). To create this protein, the $\mathrm{N}$ terminal portion of Ang1 was replaced with the short coiled-coil domain of cartilage oligomeric matrix protein (COMP). COMP-Ang1 is more potent than native Ang1 in phosphorylating the Tie2 receptor and Akt in primary cultured endothelial cells. Thus, COMP-Ang1 is an effective alternative to native Ang1 for therapeutic application in vivo. However, little is known about the role of COMPAng1 in allergic airway diseases including bronchial asthma.

In the present study, we have used a mouse model for allergic airway disease to determine effects of COMP-Ang1 on allergen-induced bronchial inflammation and airway hyper-responsiveness. We have found that an Ang1 variant, COMP-Ang1 reduced bronchial inflammation and airway hyper-responsiveness and prevented vascular leakage in a murine model of allergic airway disease. These findings suggest that COMP-Ang1 can be used as a therapeutic agent in allergic airway disease.

\section{Materials and Methods}

\section{Animals and experimental protocol}

Female C57BL/6 mice, 8-10 wk of age and free of murine specific pathogens, were obtained from Orientbio Inc. (Seoungnam, Korea), were housed throughout the experiments in a laminar flow cabinet, and were maintained on standard laboratory ovalbumin (OVA)-free chow ad libitum. All experimental animals used in this study were under a protocol approved by the Institutional Animal Care and Use Committee of the Chonbuk National University Medical School. Mice were sensitized on days 1 and 14 by i.p. injection of 20 $\mu \mathrm{g}$ OVA (Sigma-Aldrich, St. Louis, MO) emulsified in $1 \mathrm{mg}$ of aluminum hydroxide (Pierce Chemical
Co., Rockford, IL) in a total volume of $200 \mu \mathrm{l}$, as previously described (Kwak et al., 2003). On days 21,22 , and 23 after the initial sensitization, the mice were placed in a $30 \times 10 \times 15 \mathrm{~cm}$ plastic chamber with small ventilation hole and challenged for $30 \mathrm{~min}$ with an aerosol of $3 \%$ (wt/vol) OVA in saline (or with saline alone as a control) using an ultrasonic nebulizer (NE-U12; Omron, Japan). The particle size generated by the nebulizer was 4.4 $\mu \mathrm{m}$. Bronchoalveolar lavage (BAL) was performed at $48 \mathrm{~h}$ after the last challenge. At the time of lavage, the mice ( 7 mice in each group) were sacrificed with an overdose of sodium pentobarbitone (pentobarbital sodium, $100 \mathrm{mg} / \mathrm{kg}$ of body weight, administered i.p.). The chest cavity was exposed to allow for expansion, after which the trachea was carefully incised and the catheter secured with ligatures. Filtered $300 \mu \mathrm{l}$ of prewarmed $0.9 \% \mathrm{NaCl}$ solution was slowly infused three times into the lungs and withdrawn. The aliquots were pooled and then kept at $4^{\circ} \mathrm{C}$. A part of each pool was then centrifuged and the supernatants were kept at $-70^{\circ} \mathrm{C}$ until use. Total cell numbers were counted with a hemocytometer. Smears of BAL cells were prepared with a cytospin (Thermo Electron, Waltham, MA). The smears were stained with Diff-Quik solution (Dade Diagnostics of P. R. Inc. Aguada, Puerto Rico) in order to examine the cell differentials. Two independent, blinded investigators counted the cells using a microscope. Approximately 400 cells were counted in each of four different random locations. Interinvestigator variation was $<5 \%$. The mean number from the two investigators was used to estimate the cell differentials.

\section{Administration of COMP-Ang1}

We have produced COMP-Ang1 as previously described (Cho et al., 2004a; Hwang et al., 2005). COMP-Ang1 $(0.1,0.5$, or $1 \mathrm{mg} / \mathrm{kg})$ suspended in PBS (vehicle control) was administered i.v. two times to each animal, once on day 21 ( $1 \mathrm{~h}$ before the first airway challenge with OVA) and the second time on day 24 ( $24 \mathrm{~h}$ after the last airway challenge with OVA).

\section{Immunohistochemical localization of administered COMP-Ang1}

For immunohistochemical localization of administered COMP-Ang1 mice were given COMP-Ang1 i.v. and sacrificed at the indicated times as previously described (Cho et al., 2004b). Lungs were harvested, cryo-sectioned, fixed with $1 \%$ paraformaldehyde for $5 \mathrm{~min}$, embedded in paraffin, and 
immunostained with anti-Ang1 polyclonal Ab (PAhAng1FD-1). Signals were visualized with the Cell and Tissue Staining Kit (R\&D Systems, Minneapolis, MN), and counter-stained with Meyer's hematoxylin. The PA-hAng1FD-1 Ab was produced by immunization of rabbit using recombinant human Ang1 protein as an Ag. PA-hAng1FD-1 is specific to the fibrinogen domain of human and mouse Ang1 and does not cross-react with other angiopoietins. It does work to detect exogenous COMP-Ang1 and endogenous Ang 1 by immunoblotting, but it has very low sensitivity for detecting endogenous Ang1 in tissue by immunohistochemistry.

\section{Histology and immunohistochemistry}

At $48 \mathrm{~h}$ after the last challenge, lungs were removed from the mice after sacrifice. Before the lungs were removed, the lungs and trachea were filled intratracheally with a fixative $(0.8 \%$ formalin, $4 \%$ acetic acid) using a ligature around the trachea. Lung tissues were fixed with $10 \%$ ( $\mathrm{vol} / \mathrm{vol}$ ) neutral buffered formalin. The specimens were dehydrated and embedded in paraffin. For histological examination, $4-\mu \mathrm{m}$ sections of fixed embedded tissues were cut on a Leica model 2165 rotary microtome (Leica, Nussloch, Germany), placed on glass slides, deparaffinized, and stained sequentially with hematoxylin 2 and eosin-Y (Richard-Allan Scientific, Kalamazoo, MI), Congo red, or periodic acid-Schiff (PAS) stain. Inflammation score was graded by three independent blinded investigators. The degree of peribronchial and perivascular inflammation was evaluated on a subjective scale of 0 to 3 , as described elsewhere (Tournoy et al., 2000). A value of 0 was adjudged when no inflammation was detectable, a value of 1 for occasional cuffing with inflammatory cells, a value of 2 for most bronchi or vessels surrounded by thin layer (one to five cells) of inflammatory cells, and a value of 3 when most bronchi or vessels were surrounded by a thick layer (more than five cells) of inflammatory cells. For immunohistochemistry of vascular cell adhesion molecule1 (VCAM)-1, the deparaffinized 4- $\mu \mathrm{m}$ sections were incubated sequentially in accordance with the R. T. U. Vectastain Universal Quick kit instruction from Vector Laboratories (Burlingame, CA). Briefly, the slides were incubated in Endo/Blocker (Biomeda, Foster City, CA) for 5 min and then in pepsin solution for $4 \mathrm{~min}$ at $40^{\circ} \mathrm{C}$. The slides were incubated in normal horse serum for $15 \mathrm{~min}$ at room temperature. The slides were then probed with an affinity-purified rabbit polyclonal VCAM-1 IgG (Santa Cruz Biotechnology, Santa Cruz, CA) overnight at $4^{\circ} \mathrm{C}$, and were incubated with prediluted biotinylated pan-specific IgG for $10 \mathrm{~min}$. The slides were incubated in streptavidin/peroxidase complex reagent for $5 \mathrm{~min}$, and then in 3-amino-9-ethylcarbazole substrate kit for $12 \mathrm{~min}$. For the control, sections of lung tissue from mice were treated without the primary $A b$ under the same conditions. After immunostaining, the slides were counterstained with Gill's hematoxylin in $20 \%$ ethylene glycol for $1 \mathrm{~min}$ and then mounted with Aqueous Mounting Medium (InnoGenex, San Ramon, CA) and photomicrographed (Vanox T; Olympus, Tokyo, Japan).

\section{Quantification of airway mucus}

To quantitate the level of mucus expression in the airway, the numbers of PAS-positive and PASnegative epithelial cells in individual bronchioles were counted as described previously (Ikeda et al., 2003). At least 10 randomly selected mediumsized bronchi (defined by having approximately 100-150 luminal airway epithelial cells) were counted in each slide. Results are expressed as the percentage of PAS-positive cells per bronchiole that is calculated from the number of PAS-positive epithelial cells per bronchiole divided by the total number of epithelial cells of each bronchiole.

\section{Western blot analysis}

Lung tissues were homogenized in the presence of protease inhibitors to obtain extracts of proteins. Protein concentrations were determined using the Bradford reagent (Bio-Rad Laboratories, Hercules, CA). Samples were loaded on a SDS-PAGE gel. After electrophoresis at $120 \mathrm{~V}$ for $90 \mathrm{~min}$, separated proteins were transferred to PDVF membranes (Amersham Pharmacia Biotech, Piscataway, $\mathrm{NJ})$ by the wet transfer method $(250 \mathrm{~mA}, 90$ $\mathrm{min})$. Nonspecific sites were blocked with $5 \%$ non-fat dry milk in Tris-buffered saline Tween 20 (TBST; $25 \mathrm{mmol} / \mathrm{L}$ Tris, $\mathrm{pH} 7.5,150 \mathrm{mmol} / \mathrm{L} \mathrm{NaCl}$, $0.1 \%$ Tween 20 ) for $1 \mathrm{~h}$, and the blots were then incubated with an anti-TNF- $\alpha$ Ab (R\&D Systems), anti-IL-1 $\beta$ Ab (R\&D Systems), anti-IL-4 Ab (Serotec Ltd, Oxford, United Kingdom), anti- IL-5 Ab (Santa Cruz Biotechnology), anti-IL-13 Ab (R\&D Systems), anti-intercellular adhesion molecule-1 (ICAM-1) Ab (Santa Cruz Biotechnology), and anti-VCAM-1 Ab (Santa Cruz Biotechnology), anti-eotaxin Ab (Abcam Ltd., Cambridge, United Kingdom), anti-RANTES Ab (Abcam Ltd.), anti-IFN- $\gamma$ Ab (Santa Cruz Biotechnology), and anti-VEGF Ab (Santa Cruz Biotechnology) overnight at $4^{\circ} \mathrm{C}$. Anti-rabbit or antimouse HRP-conjugated IgG was used to detect 
binding of $\mathrm{Ab}$. The membranes were stripped and reblotted with anti-actin $\mathrm{Ab}$ (Sigma-Aldrich) to verify equal loading of protein in each lane. The binding of the specific $A b$ was visualized by exposing to photographic film after treating with enhanced chemiluminescence system reagents (Amersham Pharmacia Biotech).

\section{Measurement of cytokines and VEGF}

Levels of TNF- $\alpha$, IL-1 $\beta, \mathrm{IL}-4, \mathrm{IL}-5, \mathrm{IL}-13$, and VEGF were quantified in the supernatants of $B A L$ fluids by enzyme immunoassays according to the manufacturer's protocol (TNF- $\alpha, \mathrm{IL}-1 \beta, \mathrm{IL}-4$, and IL-5; Endogen, Inc., Woburn, MA, IL-13, and VEGF; R\&D Systems). Sensitivities for TNF- $\alpha$, IL-1 $\beta$, IL-4, IL-5, IL-13, and VEGF assays were 10, $3,5,5,1.5$, and $3 \mathrm{pg} / \mathrm{ml}$, respectively.

\section{Measurement of plasma exudation}

To assess lung permeability, Evans blue dye (EBD) was dissolved in $0.9 \%$ saline at a final concentration of $5 \mathrm{mg} / \mathrm{ml}$. Animals were weighed and injected with $20 \mathrm{mg} / \mathrm{kg}$ EBD in the tail vein. After 30 min, the animals were killed and their chests were opened. Normal saline containing $5 \mathrm{mM}$ EDTA was perfused through the aorta until all venous fluid returning to the opened right atrium was clear. The lungs were removed and weighed wet. EBD was extracted in $2 \mathrm{ml}$ formamide and kept in a water bath at $60^{\circ} \mathrm{C}$ for $3 \mathrm{~h}$, and the absorption of light at $620 \mathrm{~nm}$ was measured in a spectrophotometer (Eppendorf Biophotometer, Hamburg, Germany). The dye extracted was quantified by interpolation against a standard curve of dye concentration in the range of $0.01-10 \mu \mathrm{g} / \mathrm{ml}$ and is expressed as $\mathrm{ng}$ of dye/mg of wet lung.

\section{Determination of airway responsiveness to methacholine}

Airway responsiveness was assessed as a change in airway function after challenge with aerosolized methacholine via airways, as described elsewhere (Lee et al., 2006). Anesthesia was achieved with $80 \mathrm{mg} / \mathrm{kg}$ of pentobarbital sodium injected i.p.. The trachea was then exposed through midcervical incision, tracheostomized, and an 18gauge metal needle was inserted. Mice were connected to a computer-controlled small animal ventilator (flexiVent; SCIREQ, Montreal, PQ, Canada). The mouse was quasisinusoidally ventilated with nominal tidal volume of $10 \mathrm{ml} / \mathrm{kg}$ at a frequency of 150 breaths/min and a positive endexpiratory pressure of $2 \mathrm{~cm} \mathrm{H}_{2} \mathrm{O}$ to achieve a mean lung volume close to that during spontaneous breathing. This was achieved by connecting the expiratory port of the ventilator to water column. Methacholine aerosol was generated with an in-line nebulizer and administered directly through the ventilator. To determine the differences in airway response to methacholine, each mouse was challenged with methacholine aerosol in increasing concentrations (2.5-50 $\mathrm{mg} / \mathrm{ml}$ in saline). After each methacholine challenge, the data of airway resistance $\left(R_{L}\right)$ was continuously collected. Maximum values of $R_{L}$ were selected to express changes in airway function which was represented as a percentage change from baseline after saline aerosol.

\section{Densitometric analysis and statistics}

All immunoreactive signals were analyzed by densitometric scanning (Gel Doc XR; Bio-Rad Laboratories). Data were expressed as mean \pm SEM. Statistical comparisons were performed using one-way ANOVA followed by the Scheffe's test. Pearson's correlation was calculated to assess the correlation between data. Significant differences between two groups were determined using the unpaired Student's $t$ test. Statistical significance was set at $P<0.05$.

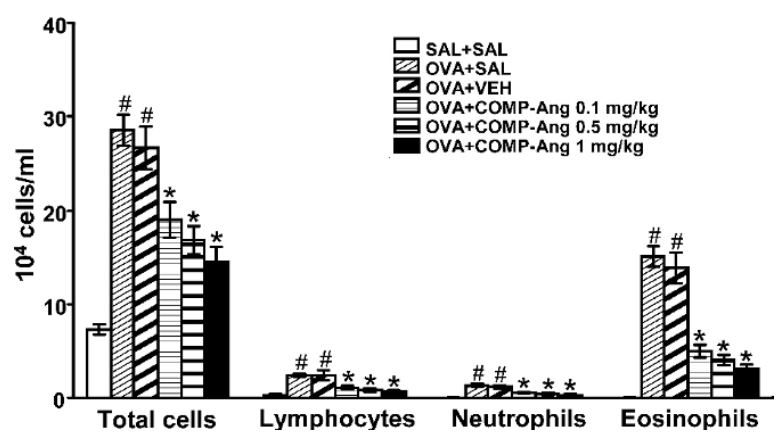

Figure 1. Effect of COMP-Ang1 on total and differential cellular components of BAL fluids. The numbers of each cellular component of BAL fluid from saline-inhaled mice with the administration of saline (SAL + SAL), OVA-inhaled mice with the administration of saline (OVA + SAL), OVA-inhaled mice with the administration of drug vehicle (OVA + VEH), OVA-inhaled mice with the administration of COMP-Ang1 $1 \mathrm{mg} / \mathrm{kg}$ (OVA + COMP- Ang1 $1 \mathrm{mg} / \mathrm{kg}$ ), OVA-inhaled mice with the administration of COMP-Ang1 $0.5 \mathrm{mg} / \mathrm{kg}$ (OVA + COMP-Ang1 $0.5 \mathrm{mg} / \mathrm{kg}$ ), and OVA-inhaled mice with the administration of COMP-Ang1 $0.1 \mathrm{mg} / \mathrm{kg}$ (OVA + COMP-Ang1 $0.1 \mathrm{mg} / \mathrm{kg}$ ) were counted at $48 \mathrm{~h}$ after the last challenge. Bars represent mean ( SEM from 7 mice per group. ${ }^{P}<0.05$ vs. SAL $+\mathrm{SAL} ;{ }^{*} P<0.05$ vs. OVA + SAL. 


\section{Results}

\section{Effect of COMP-Ang1 on cellular changes in BAL fluids}

Numbers of total cells, eosinophils, lymphocytes,
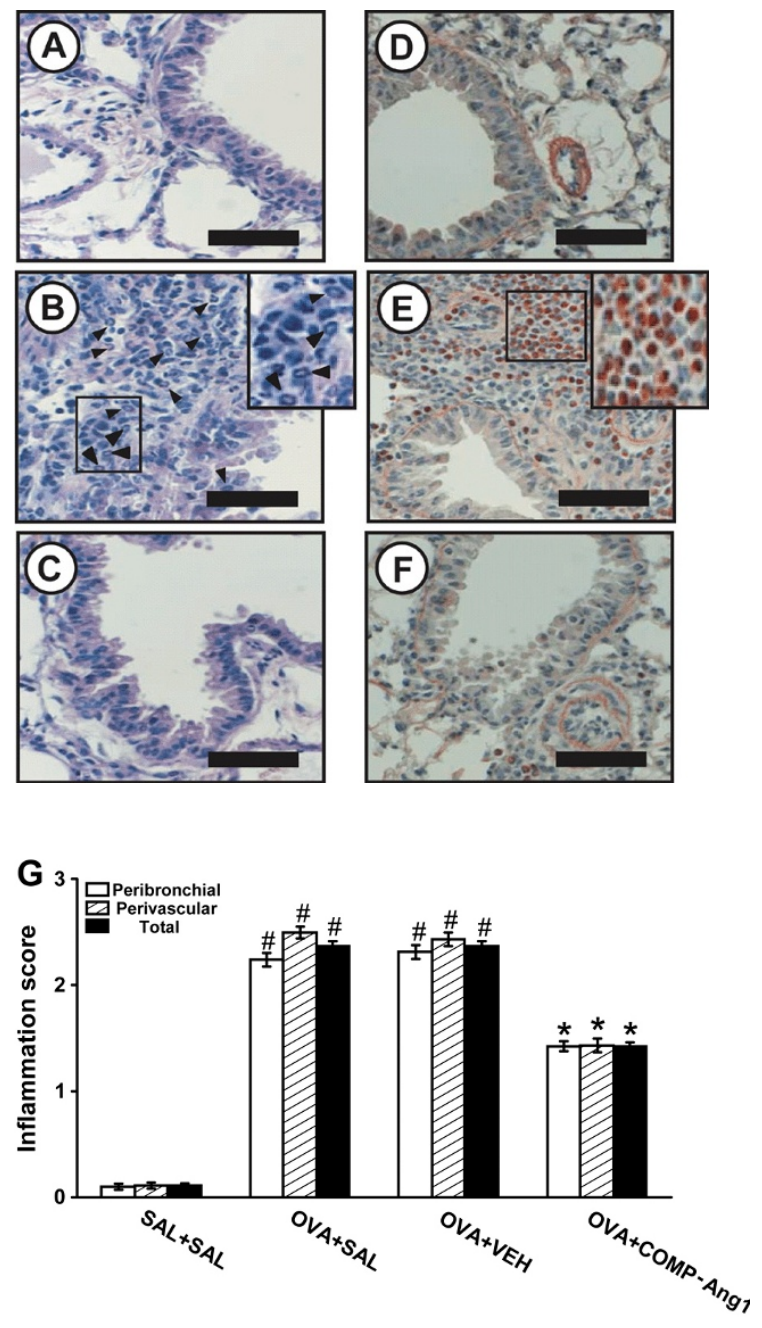

Figure 2. Effect of COMP-Ang1 on pathologic changes in lung tissues. (A-F) Representative hematoxylin 2 and eosin-Y stained sections (A-C) and Congo red-stained sections of the lungs (D-F). Sampling was performed at $48 \mathrm{~h}$ after the last challenge in saline-inhaled mice with the administration of saline (A and D), OVA-inhaled mice with the administration of saline ( $B$ and $E$ ), and OVA-inhaled mice with the administration of COMP-Ang1 $0.5 \mathrm{mg} / \mathrm{kg}$ (C and F). Eosinophils indicated by arrows (B). Eosinophils can be identified by the orange-red staining cytoplasm (D-F). Bars indicate $50 \mu \mathrm{m}$. (G) Peribronchial, perivascular, and total lung inflammation were measured at $48 \mathrm{~h}$ after the last challenge in saline-challenged mice (SAL + SAL), OVA-inhaled mice with the OVA-inhaled mice with the administration of saline (OVA + SAL), and OVA-inhaled mice with the administration of COMP-Ang1 $0.5 \mathrm{mg} / \mathrm{kg}$ (OVA + COMP-Ang1). Total lung inflammation was defined as the average of the peribronchial and perivascular inflammation scores. Bars represent mean \pm SEM from 7 mice per group. ${ }^{*} P<0.05$ vs. SAL + SAL; ${ }^{*} P<$ 0.05 vs. OVA + SAL. and neutrophils in BAL fluids were increased significantly at $48 \mathrm{~h}$ after OVA inhalation compared with the numbers after saline inhalation (Figure 1). The increased numbers of these cells were significantly reduced by the administration of COMPAng1.

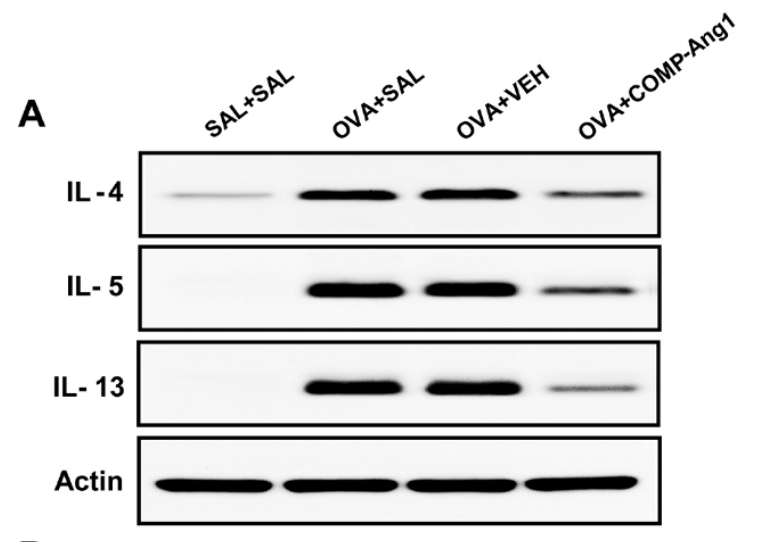

B

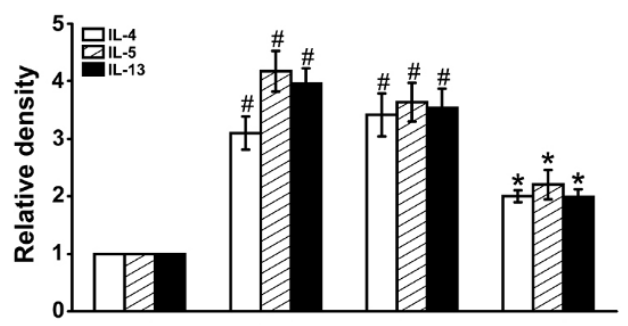

C

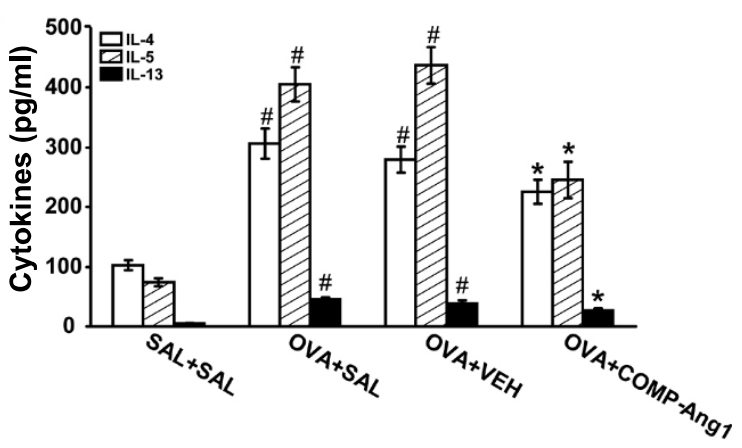

Figure 3. Effect of COMP-Ang1 on expression of Th2 cytokines in lung tissues and BAL fluids of OVA-sensitized and -challenged mice. (A) Western blotting of IL-4, IL-5, and IL-13 in lung tissues. (B) Densitometric analyses are presented as the relative ratio of IL-4, IL-5, and IL-13 to actin. The relative ratio of the molecules in the lung tissues of $S A L+$ SAL is arbitrarily presented as 1. (C) Enzyme immunoassay of IL-4, IL-5, and IL-13 in BAL fluids. Sampling was performed at $48 \mathrm{~h}$ after the last challenge in saline-inhaled mice with the administration of saline $(S A L+$ $S A L)$, OVA-inhaled mice with the administration of saline (OVA + SAL), OVA-inhaled mice with the administration of drug vehicle (OVA + VEH), and OVA-inhaled mice with the administration of COMP-Ang1 $0.5 \mathrm{mg} / \mathrm{kg}$ (OVA + COMP-Ang1). Bars represent mean \pm SEM from 7 mice per group. ${ }^{\#} P<0.05$ vs. SAL + SAL; ${ }^{*} P<0.05$ vs.OVA + SAL. 


\section{Effect of COMP-Ang1 on pathological changes of OVA-sensitized and -challenged mice}

Histologic analyses revealed typical pathologic features of allergic airway disease in the OVAchallenged mice. Numerous inflammatory cells, especially eosinophils, infiltrated around the bronchioles (Figure 2B and $\mathrm{E}$ ) as compared to the control (Figure 2A and D). COMP-Ang1-treated mice (Figure $2 \mathrm{C}$ and $\mathrm{F}$ ) showed marked reductions in the infiltration of inflammatory cells in the peribronchiolar region and in the number of inflammatory cells, especially eosinophils. The scores of peribronchial, perivascular, and total lung inflammation were increased significantly at $48 \mathrm{~h}$ after OVA inhalation compared with the scores after saline inhalation (Figure 2G). The increased inflammation scores were significantly reduced by the administration of COMP-Ang1.

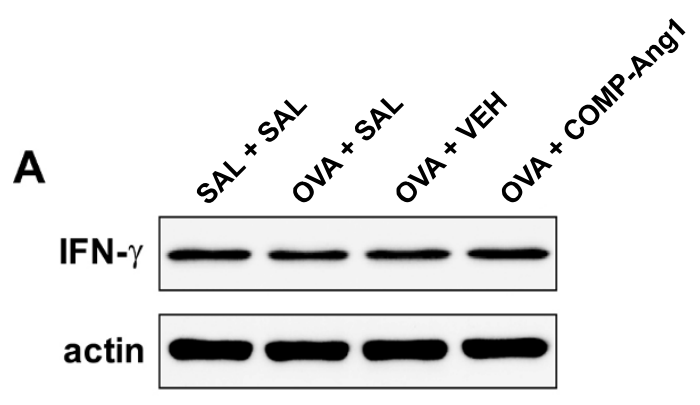

B

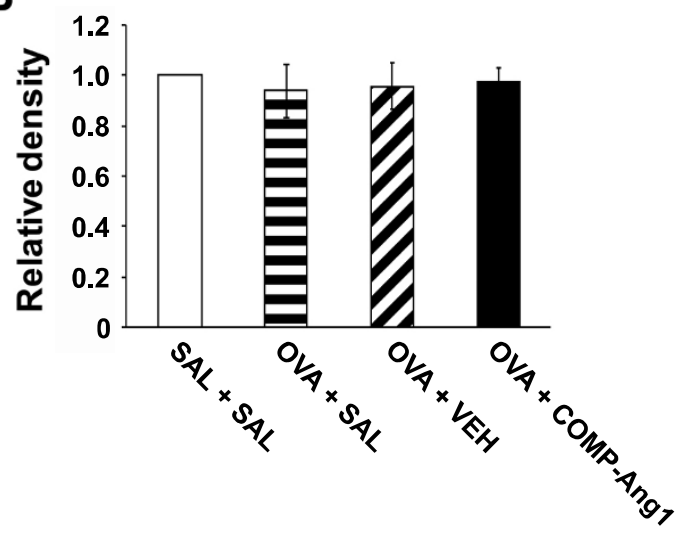

Figure 4. Effect of COMP-Ang1 on expression of Th1 cytokine, IFN- $\gamma$ in lung tissues of OVA-sensitized and -challenged mice. (A) Western blotting of IFN- $\gamma$ in lung tissues. (B) Densitometric analyses are presented as the relative ratio of IFN- $\gamma$ to actin. The relative ratio of the molecules in the lung tissues of SAL + SAL is arbitrarily presented as 1. Sampling was performed at $48 \mathrm{~h}$ after the last challenge in saline-inhaled mice with the administration of saline (SAL + SAL), OVA-inhaled mice with the administration of saline (OVA + SAL), OVA-inhaled mice with the administration of drug vehicle (OVA + VEH), and OVA-inhaled mice with the administration of COMP-Ang1 $0.5 \mathrm{mg} / \mathrm{kg}$ (OVA + COMP-Ang1). Bars represent mean \pm SEM from 7 mice per group. ${ }^{\#} P<0.05$ vs. SAL + SAL; ${ }^{*} P<0.05$ vs. OVA + SAL.

\section{Effect of COMP-Ang1 on IL-4, IL-5, and IL-13 levels}

Western blot analysis revealed that IL-4, IL-5, and IL-13 protein levels in lung tissues were increased significantly at $48 \mathrm{~h}$ after OVA inhalation compared with the levels after saline inhalation. The increased IL-4, IL-5, and IL-13 levels after OVA inhalation were significantly reduced by the administration of COMP-Ang1 (Figure $3 \mathrm{~A}$ and $\mathrm{B}$ ). Consistent with these results, enzyme immunoassays showed that levels of IL-4, IL-5, and IL-13 in BAL fluids were also increased significantly at 48 $\mathrm{h}$ after OVA inhalation compared with the levels after saline inhalation (Figure $3 \mathrm{C}$ ). The increased IL-4, IL-5, and IL-13 levels were significantly reduced by the administration of COMP-Ang1.

\section{Effect of COMP-Ang1 on INF- $\gamma$ levels}

Western blot analysis showed the levels of IFN- $\gamma$ in OVA-inhaled mice administered COMP-Ang1 (Figure 4). We have found that there were no significant differences in IFN- $\gamma$ protein levels in any of the groups tested.

\section{COMP-Ang1 reduced plasma extravasation in OVA-sensitized and -challenged mice}

EBD assay revealed that plasma extravasation was significantly increased at $48 \mathrm{~h}$ after the last challenge with OVA (Figure 5). The increase in plasma extravasation was significantly reduced by the administration of the COMP-Ang1.

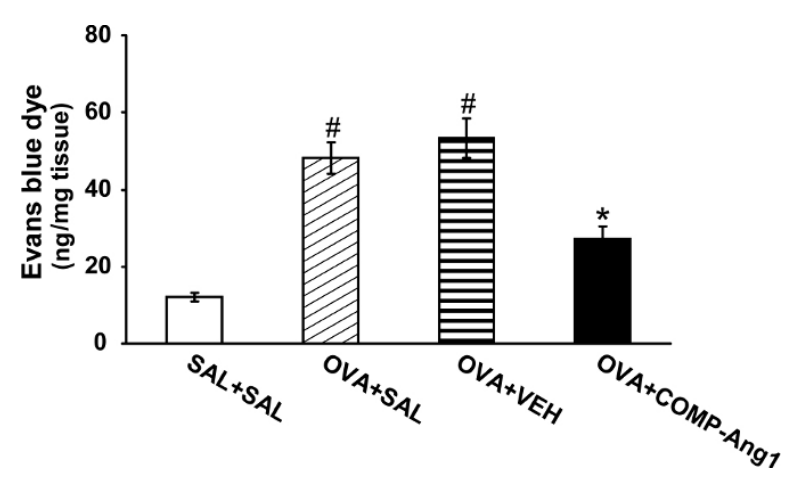

Figure 5. Effect of COMP-Ang1 on plasma exudation of OVA-sensitized and -challenged mice. EBD assay of plasma extravasation. The sampling was performed at $48 \mathrm{~h}$ after the last challenge in saline-inhaled mice with the administration of saline-inhaled mice with the administration of saline (SAL + SAL), OVA-inhaled mice with the administration of saline (OVA + SAL), and OVA-inhaled mice with the administration of COMP-Ang1 $0.5 \mathrm{mg} / \mathrm{kg}$ (OVA + COMP-Ang1). Bars represent mean \pm SEM from 7 mice per group. ${ }^{\#} P<0.05$ vs. SAL $+S A L ;{ }^{*} P<0.05$ vs. OVA + SAL. 


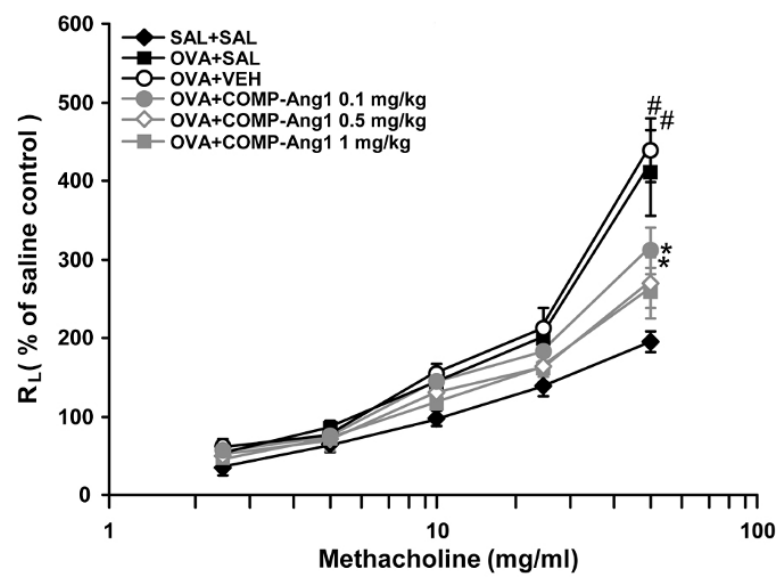

Figure 6. Effect of COMP-Ang1 on airway responsiveness in OVA-sensitized and -challenged mice. Airway responsiveness was measured at 48 $\mathrm{h}$ after the last challenge in saline-inhaled mice with the administration of saline (SAL + SAL), OVA-inhaled mice with the administration of saline (OVA + SAL), OVA-inhaled mice with the administration of drug vehicle (OVA + VEH), OVA-inhaled mice with the administration of COMP- Ang1 $1 \mathrm{mg} / \mathrm{kg}$ (OVA + COMP-Ang1 $1 \mathrm{mg} / \mathrm{kg})$, OVA-inhaled mice with the administration of COMP-Ang1 $0.5 \mathrm{mg} / \mathrm{kg}$ (OVA + COMP-Ang1 $0.5 \mathrm{mg} / \mathrm{kg}$ ), and OVA-inhaled mice with the administration of COMP-Ang1 $0.1 \mathrm{mg} / \mathrm{kg}$ (OVA + COMP-Ang1 $0.1 \mathrm{mg} / \mathrm{kg}$ ). $\mathrm{R}_{\mathrm{L}}$ values were obtained in response to increasing doses $(2.5$ to $50 \mathrm{mg} / \mathrm{ml})$ of methacholine as described in Materials and Methods. Bars represent mean \pm SEM from 7 mice per group. ${ }^{\#} P<0.05$ vs. SAL + SAL; ${ }^{*} P<0.05$ vs. OVA + SAL.
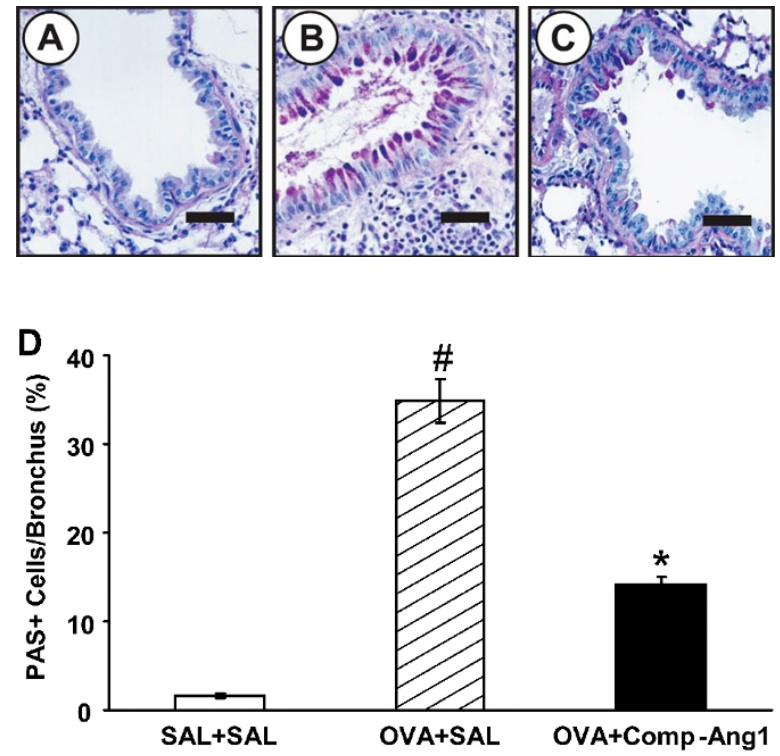

Figure 7. Effect of COMP-Ang1 on airway mucus expression in lung tissues. (A-C) Representative PAS-stained sections of the lungs. Sampling was performed at $48 \mathrm{~h}$ after the last challenge in saline-inhaled mice with the administration of saline (SAL + SAL, A), OVA-inhaled mice with the administration of saline (OVA + SAL, B), and OVA-inhaled mice with the administration of COMP-Ang1 $0.5 \mathrm{mg} / \mathrm{kg}$ (OVA + COMP-Ang1, C). (D) Quantitation of airway mucus expression. Bars represent mean \pm SEM from 7 mice per group. ${ }^{\#} P<0.05$ vs. SAL + SAL; ${ }^{*} P<0.05$ vs. $\mathrm{OVA}+\mathrm{SAL}$

\section{Effect of COMP-Ang1 on airway hyper-responsiveness}

Airway responsiveness was assessed as a percent increase of $R_{L}$ in response to increasing doses of methacholine. In OVA-sensitized and -challenged mice, the dose-response curve of percent $R_{L}$ shifted to the left compared with that of control

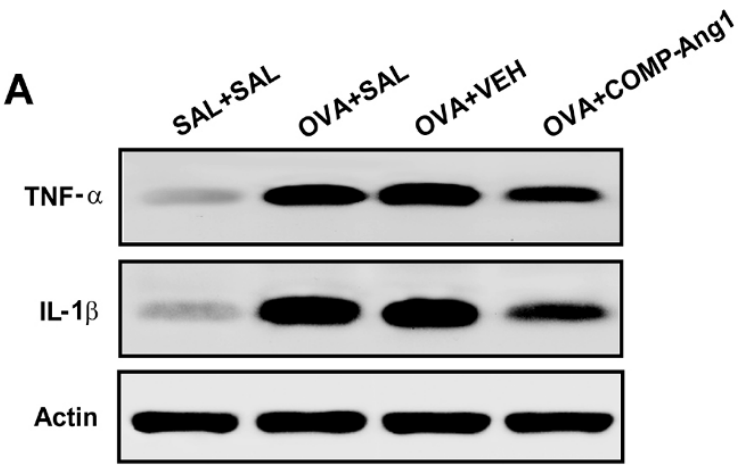

B

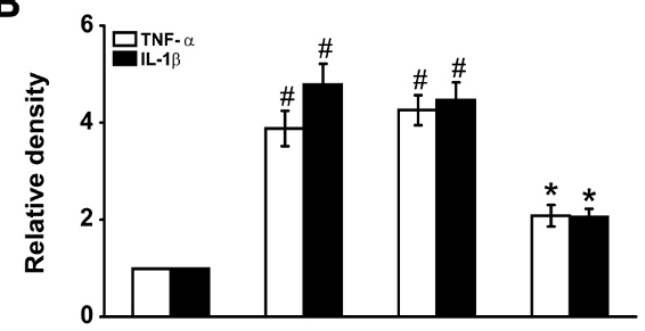

C

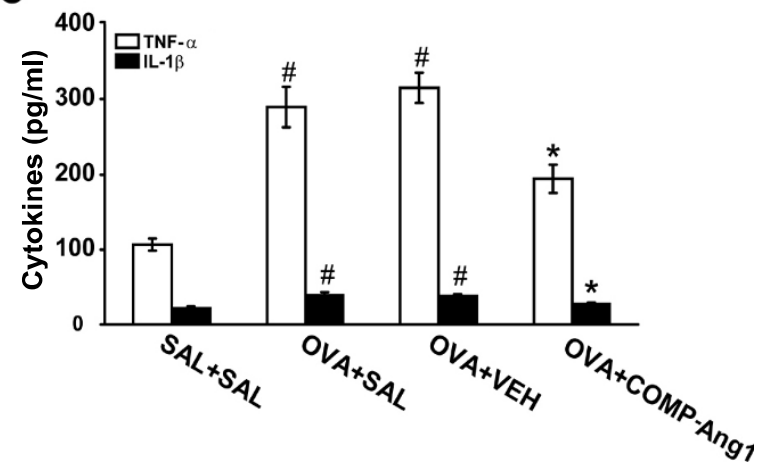

Figure 8. Effect of COMP-Ang1 on TNF- $\alpha$ and IL-1 $\beta$ protein expression in lung tissues and BAL fluids of OVA-sensitized and -challenged mice. (A) Western blotting of TNF- $\alpha$ and IL-1 $\beta$. The protein expression of these cytokines was measured at $48 \mathrm{~h}$ after the last challenge in saline-inhaled mice with the administration of saline (SAL + SAL), OVA-inhaled mice with the administration of saline (OVA + SAL), OVA-inhaled mice with the administration of drug vehicle (OVA + VEH), OVA-inhaled mice with the administration of COMP-Ang1 $0.5 \mathrm{mg} / \mathrm{kg}$ (OVA + COMP-Ang1). (B) Densitometric analyses are presented as the relative ratio of each molecule to actin. The relative ratio of each molecule in the lung tissues of $\mathrm{SAL}+\mathrm{SAL}$ is arbitrarily presented as 1. (C) Enzyme immunoassay of TNF- $\alpha$ and IL- $1 \beta$ in the BAL fluids. Bars represent mean \pm SEM from 7 mice per group. ${ }^{*} P<0.05$ vs. SAL $+S A L ;{ }^{*} P<0.05$ vs. OVA + SAL. 
mice (Figure 6). In addition, the percent $R_{L}$ produced by administration of methacholine of 50 $\mathrm{mg} / \mathrm{ml}$ increased significantly in the OVA-sensitized and -challenged mice compared with the controls. OVA-sensitized and -challenged mice treated with COMP-Ang1 showed a substantial reduction of the percent $R_{L}$ at dose of $50 \mathrm{mg} / \mathrm{ml}$ of methacholine compared with that of OVA-sensitized and -challenged mice treated with saline or drug vehicle. These results indicate that COMP-Ang1 treatment reduces OVA-induced airway hyperresponsiveness.

\section{Effect of COMP-Ang1 on airway mucus expression of OVA-sensitized and -challenged mice}

To quantitate the level of mucus expression in the airway, the number of PAS-positive and PASnegative epithelial cells in individual bronchioles was counted. The percentage of airway epithelium which stained positively with PAS in mice after
OVA inhalation was significantly increased compared with the level in control mice. The increased percentage of PAS-positive airway epithelium was decreased dramatically by the treatment of COMP. Ang1 compared with the level of OVA-sensitized and -challenged mice treated with saline (Figure 7).

\section{Effect of COMP-Ang1 on TNF- $\alpha$ and IL-1 $\beta$ levels}

Western blot analysis revealed that TNF- $\alpha$ and $\mathrm{IL}-1 \beta$ protein levels in lung tissues were increased significantly at $48 \mathrm{~h}$ after OVA inhalation compared with the levels after saline inhalation. The increased TNF- $\alpha$ and IL-1 $\beta$ levels were significantly reduced by the administration of COMP-Ang1 (Figure $8 \mathrm{~A}$ and $\mathrm{B}$ ). Consistent with these results, enzyme immunoassays revealed that levels of TNF- $\alpha$ and IL-1 $\beta$ in BAL fluids were also increased significantly at $48 \mathrm{~h}$ after OVA inhalation compared with the levels after saline inhalation (Figure $8 \mathrm{C}$ ).
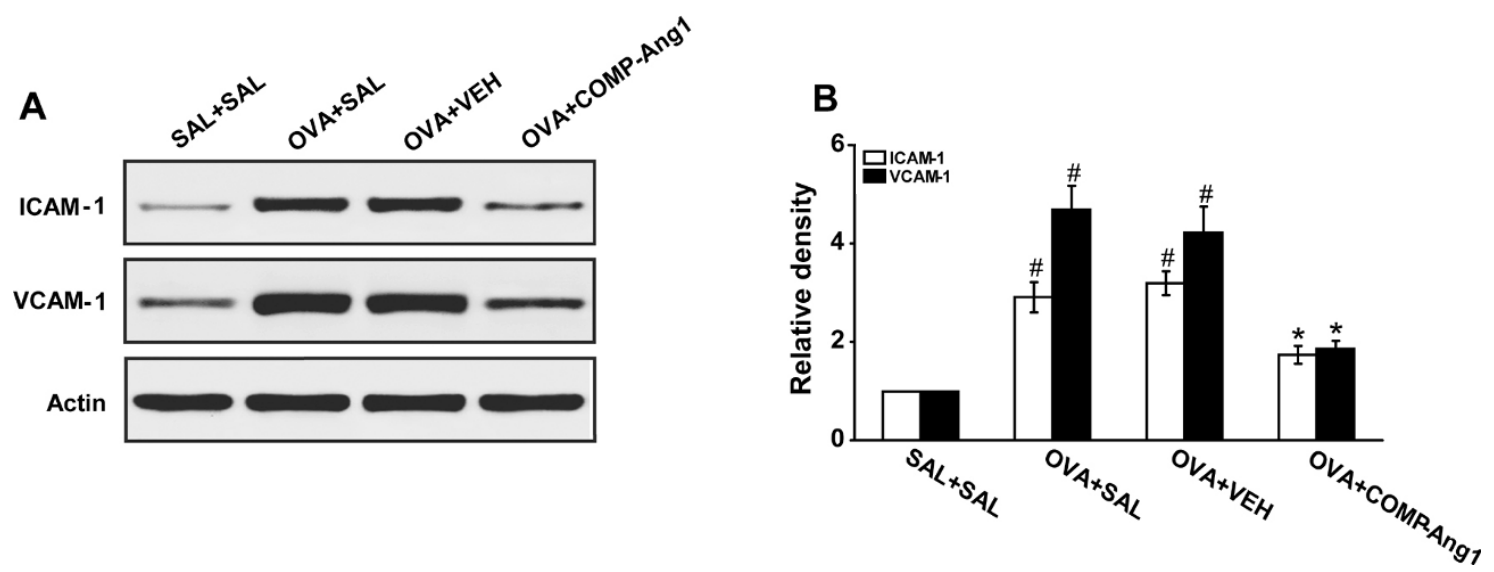

C

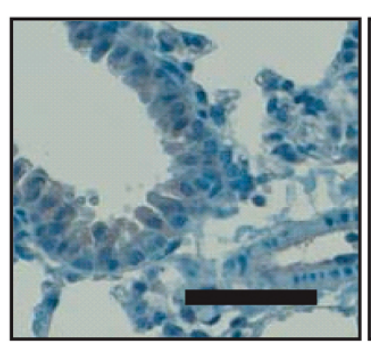

$S A L+S A L$

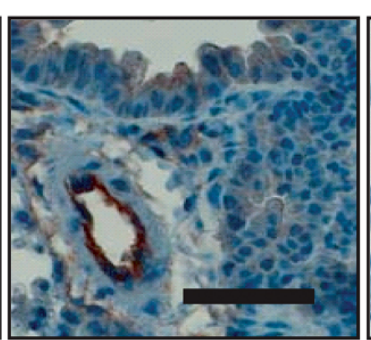

OVA+SAL

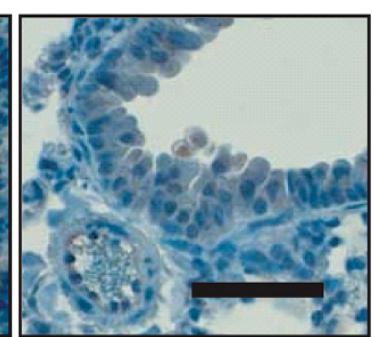

OVA+COMP-Ang1

Figure 9. Effect of COMP-Ang1 on ICAM-1 and VCAM-1 protein expression in lung tissues of OVA-sensitized and -challenged mice. (A) Western blotting of ICAM-1 and VCAM-1. Sampling was performed at $48 \mathrm{~h}$ after the last challenge in saline-inhaled mice with the administration of saline (SAL + SAL), OVA-inhaled mice with the administration of saline (OVA + SAL), OVA-inhaled mice with the administration of drug vehicle (OVA + VEH), OVA-inhaled mice with the administration of COMP-Ang1 $0.5 \mathrm{mg} / \mathrm{kg}$ (OVA + COMP-Ang1). (B) Densitometric analyses are presented as the relative ratio of each molecule to actin. The relative ratio of each molecule in the lung tissues of SAL + SAL is arbitrarily presented as 1. (C) Localization of immunoreactive VCAM-1 in lung tissues. The brown color indicates VCAM-1-positive cells. Bars indicate $50 \mu \mathrm{m}$. Bars represent mean \pm SEM from 7 mice per group. ${ }^{\sharp} P<0.05 \mathrm{vs}$. SAL $+\mathrm{SAL} ;{ }^{*} P<0.05$ vs. OVA + SAL. 
The increased TNF- $\alpha$ and IL-1 $\beta$ levels were significantly reduced by the administration of COMP. Ang1.

\section{Effect of COMP-Ang1 on ICAM-1 and VCAM-1 expression}

Western blot analysis revealed that ICAM-1 and VCAM-1 protein levels in lung tissues were increased at $48 \mathrm{~h}$ after OVA inhalation compared with the levels after saline inhalation. The increased ICAM-1 and VCAM-1 levels were reduced by the administration of COMP-Ang1 (Figure 9A and $B$ ).

Immunohistochemical analyses showed the localization of immunoreactive VCAM-1 in endothelium of pulmonary vessels, epithelial layers, and inflammatory cells around the bronchioles in OVAinduced asthmatic lungs (Figure 9C). However, immunoreactive VCAM-1 was markedly reduced in
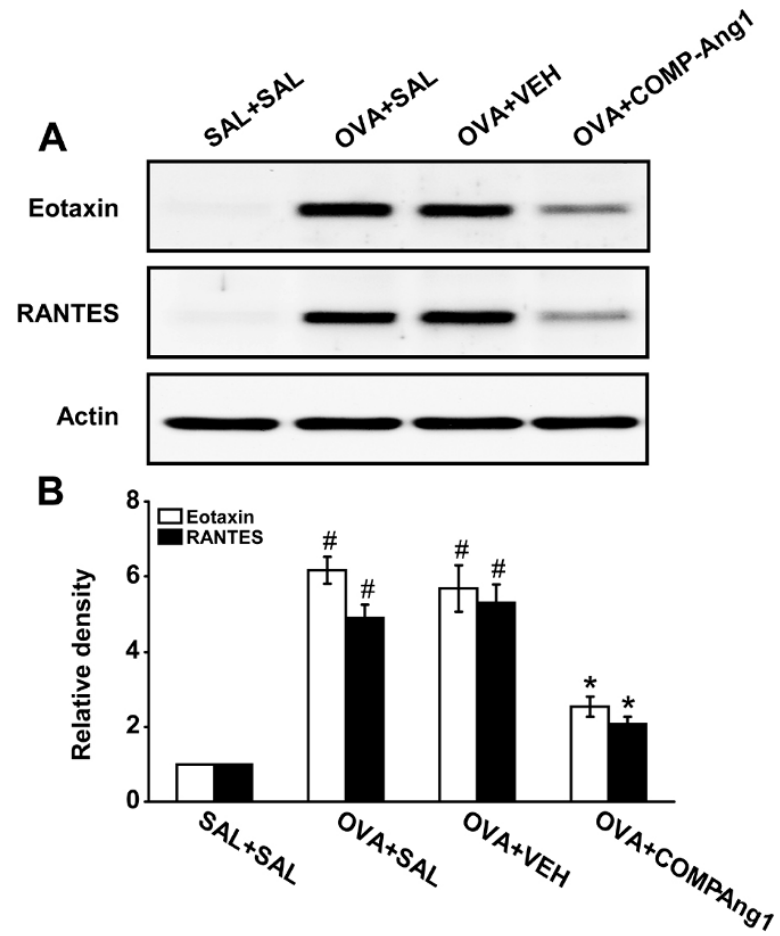

Figure 10. Effect of COMP-Ang1 on eotaxin and RANTES protein expression in lung tissues of OVA-sensitized and -challenged mice. (A) Western blotting of eotaxin and RANTES. Sampling was performed at 48 $h$ after the last challenge in saline-inhaled mice with the administration of saline (SAL + SAL), OVA-inhaled mice with the administration of saline (OVA + SAL), OVA-inhaled mice with the administration of drug vehicle (OVA + VEH), OVA-inhaled mice with the administration of COMP-Ang1 $0.5 \mathrm{mg} / \mathrm{kg}$ (OVA + COMP-Ang1). (B) Densitometric analyses are presented as the relative ratio of each molecule to actin. The relative ratio of each molecule in the lung tissues of SAL + SAL is arbitrarily presented as 1. Bars represent mean \pm SEM from 7 mice per group. ${ }^{\sharp} P<0.05$ vs. $\mathrm{SAL}+\mathrm{SAL} ;{ }^{*} P<0.05$ vs. OVA + SAL. lung tissues from saline-inhaled mice treated with saline and OVA-inhaled mice treated with COMPAng1.

\section{Effect of COMP-Ang1 on levels of eotaxin and RANTES}

Western blot analysis revealed that levels of eotaxin and RANTES in lung tissues were increased at $48 \mathrm{~h}$ after OVA inhalation compared with the levels in the control mice (Figure 10). The increased eotaxin and RANTES levels were decreased by the administration of COMP-Ang1.
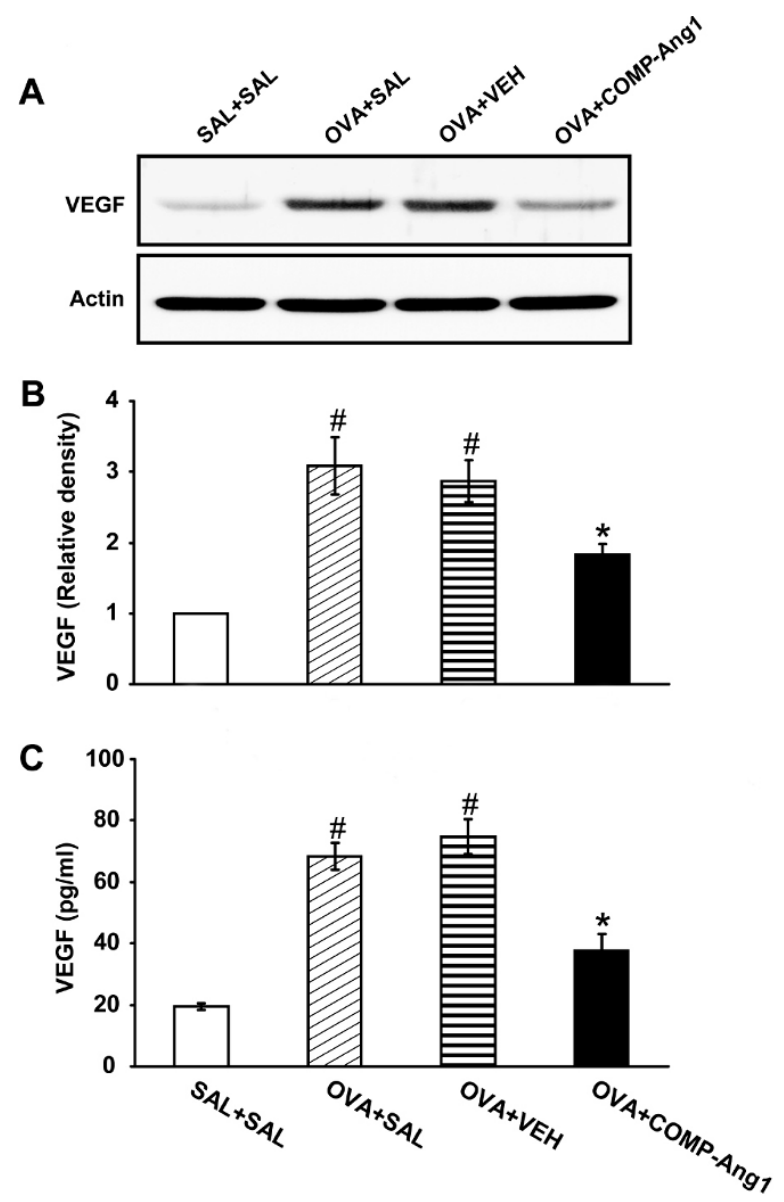

Figure 11. Effect of COMP-Ang1 on VEGF protein levels in lung tissues and in BAL fluids and plasma exudation of OVA-sensitized and -challenged mice. (A) Western blotting of VEGF. (B) Densitometric analyses are presented as the relative ratio of VEGF to actin. The relative ratio of VEGF in the lung tissues of SAL + SAL is arbitrarily presented as 1. (C) Enzyme immunoassay of VEGF. The sampling was performed at 48 $\mathrm{h}$ after the last challenge in saline-inhaled mice with the administration of saline-inhaled mice with the administration of saline $(S A L+S A L)$, OVA-inhaled mice with the administration of saline (OVA + SAL), and OVA-inhaled mice with the administration of COMP-Ang1 $0.5 \mathrm{mg} / \mathrm{kg}$ (OVA + COMP-Ang1). Bars represent mean \pm SEM from 7 mice per group. ${ }^{\#} P<0.05$ vs. SAL $+S A L ;{ }^{*} P<0.05$ vs. OVA + SAL. 


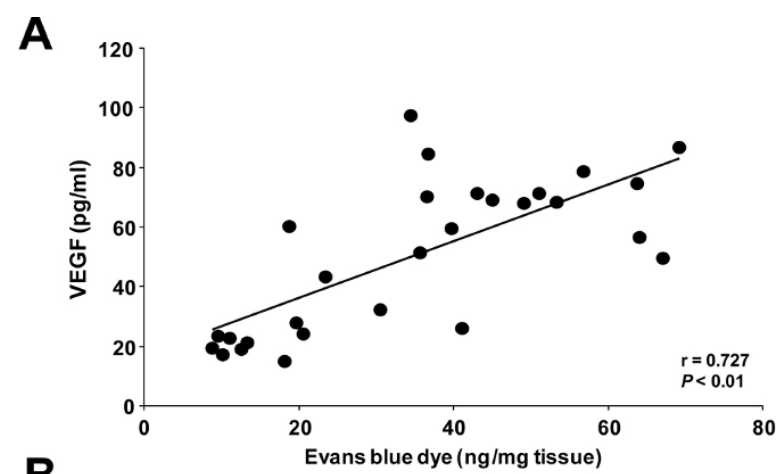

B

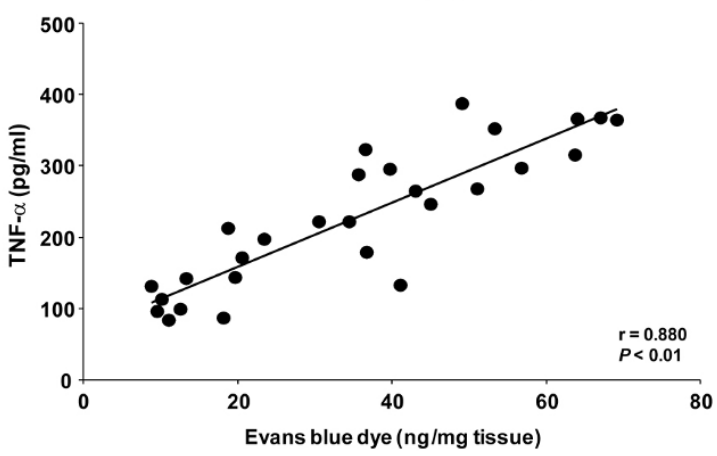

Figure 12. Correlations of levels of VEGF (A) and TNF- $\alpha(B)$ in BAL fluids with levels of plasma exudation in OVA-inhaled mice. Sampling was performed at $48 \mathrm{~h}$ after the last challenge in saline-sensitized and -challenged mice and OVA-sensitized and -challenged mice.

\section{Effect of COMP-Ang1 on VEGF protein levels}

Western blot analysis showed that levels of VEGF in lung tissues were increased at $48 \mathrm{~h}$ after OVA inhalation compared with the levels in the control mice (Figure $11 \mathrm{~A}$ and $\mathrm{B}$ ). The increased VEGF levels were decreased by the administration of COMP-Ang1. Consistent with these results, enzyme immunoassay revealed that COMP-Ang1 reduced the increased levels of VEGF in the BAL fluids after OVA inhalation (Figure 11C).

\section{Correlations between levels of VEGF or TNF- $\alpha$ and vascular permeability in lungs of OVA-inhaled mice}

The levels of VEGF or TNF- $\alpha$ in BAL fluids showed significantly positive correlations with the levels of plasma exudation in OVA-inhaled mice (VEGF; $r=0.727, P<0.01$ and TNF- $\alpha ; r=0.880$, $P<0.01$ ) (Figure 12).

\section{Distribution and localization of COMP-Ang1}

To determine the distribution and localization of COMP-Ang1 in lung tissues, we performed immunohistochemical localization after i.v. administration of COMP-Ang1. At 10 min after administra-

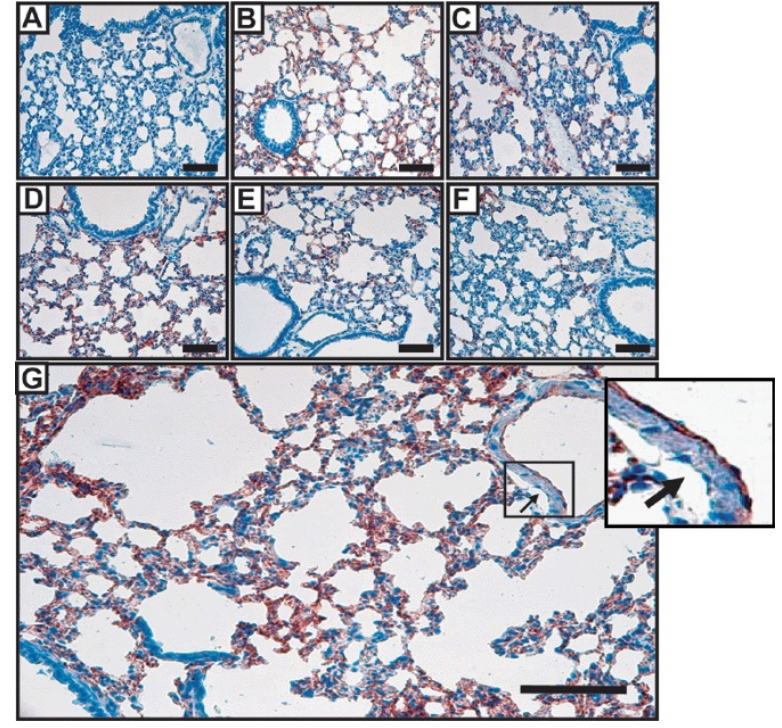

Figure 13. COMP-Ang1 injected i.v. localizes in vascular endothelial cells of lung. Mice were given COMP-Ang1 i.v. and sacrificed after following times ( $A, 0$ min; B, 10 min; C, 30 min; D, 60 min; E, 6 h; F, 24 h). The specimens were immunostained with anti-COMP polyclonal antibody and counter-stained with Meyer's hematoxylin. (A-G) Representative photomicrographs showing localization of immunoreactive COMP-Ang1 (G, higher magnification image). The arrow indicates a vessel; Reddishbrown colors are immuno-positive signals. Bars indicate $100 \mu \mathrm{m}$.

tion of COMP-Ang1, an abundant amount of COMP-Ang1 was located in vascular endothelial cells and alveolar septae of the lungs (Figure 13B and G). Similar findings were observed up to $24 \mathrm{~h}$, although the amount of protein had decreased in the lung (Figure $13 \mathrm{C}$ and $\mathrm{F}$ ).

\section{Discussion}

Bronchial asthma is characterized by inflammation of the airways which is usually accompanied by increased vascular permeability, resulting in plasma exudation. Exudation of plasma proteins into the airways plays a role in airway inflammation and hyper-responsiveness. Ang1 protein has potential therapeutic application in prevention of vascular leakage (Thurston et al., 2000). Our present study with the OVA-induced murine model of allergic airway disease revealed that COMP. Ang1, which is more potent than native Ang1 in phosphorylating the Tie2 receptor in lung endothelial cells, reduces antigen-induced airway infiltration of inflammatory cells, increased secretion of Th2 cytokines in lungs, airway hyper-responsiveness to methacholine, and increased vascular permeability. These findings suggest that COMP-Ang1 attenuates antigen-induced airway 
inflammation and hyper-responsiveness and prevents vascular leakage in mice.

Recently, we have reported that increased vascular permeability is associated with bronchial inflammation and airway hyper-responsiveness in a murine model of asthma (Lee et al., 2002, 2004). Consistent with these observations, in this study we have found that amounts of plasma extravasation were greatly enhanced after the OVA inhalation in a murine model of allergic airway disease. Interestingly, administration of COMPAng1 reduced the bronchial inflammation, airway hyper-responsiveness, and vascular leakage. These results suggest that treatment of COMP. Ang1 may decrease the airway inflammation and hyper-responsiveness by inhibiting vascular permeability increased. Increased vascular permeability causes leakage of intravascular components, including plasma extravasation. Although the pathogenesis of asthma induced by plasma extravasation is not clearly defined, plasma protein leakage has been implicated to play a role in the induction of a thickened, engorged, and edematous airway wall, resulting in the airway luminal narrowing. Exudation of plasma proteins into the airways correlates with bronchial hyper-reactivity (Van de Graaf et al., 1991). It is also possible that the plasma exudates may readily pass the inflamed mucosa and reach the airway lumen through leaky epithelium, thus compromising epithelial integrity and reducing ciliary function and mucus clearance (Foster et al., 1982; Persson, 1996).

Although some investigators have described a role for Ang1 in promoting chemotaxis and migration of leukocytes in vitro (Feistritzer et al., 2004; Lemieux et al., 2005), Ang1 has also been shown to reduce leukocyte trafficking in inflammation through the modulation of various inflammatory mediators (Kim et al., 2001; Pizurki et al., 2003; Witzenbichler et al., 2005). Th2 cytokines, adhesion molecules, chemokines, and VEGF play a crucial role in the chemotactic responses for leukocytes, including eosinophils (Wegner et al., 1990; Montefort and Holgate, 1991; Moser et al., 1992; Seder et al., 1992; Foster et al., 1996; Pawankar et al., 1997; Dabbagh et al., 1999). In the present study, the increased levels of Th2 cytokines (IL-4, IL-5, and IL-13), adhesion molecules (ICAM-1 and VCAM-1), chemokines (eotaxin and RANTES), and VEGF in lungs after OVA inhalation were significantly decreased by treatment of COMP-Ang1 in a murine model of allergic airway disease. Therefore, these observations suggest that COMP-Ang1 can decrease the migration of inflammatory cells by reducing chemotactic effects on leukocytes as well as by inhibiting the increased vascular permeability.

IL-4 regulates allergic inflammation by promoting Th2 cell differentiation, IgE synthesis and its receptor up-regulation, VCAM-1 expression, and airway hyper-secretion (Moser et al., 1992; Seder et al., 1992; Pawankar et al., 1997; Dabbagh et al., 1999). IL-5 promotes eosinophilic inflammation and infiltration into airways (Foster et al., 1996). IL-13 is a cytokine produced primarily by activated Th2 cells, promotes B-cell differentiation, and is capable of inducing isotype-switching in B cells to produce lgG4 and IgE (Cocks et al., 1993). We have found that the increased levels of these Th2 cytokines in the OVA-induced lungs were significantly reduced by i.v. administration of COMPAng1. Our data also suggest that blockade of vascular leakage by the administration of COMP. Ang1 reduces secretion of Th2 cytokines in lungs.

Cytokine-inducible leukocyte-endothelial adhesion molecules are important in the recruitment and migration of leukocytes to the sites of inflammation (Wegner et al., 1990; Montefort and Holgate, 1991). Expression of ICAM-1 or VCAM-1 is modulated by cytokines such as TNF- $\alpha, \mathrm{IL}-1 \beta$, and IL-4 (Dustin et al., 1986; Osborn et al., 1989; Hirata et al., 1998). Our data have demonstrated that COMP-Ang1 reduced the increased numbers of inflammatory cells in the airways which are the source of TNF- $\alpha, \mathrm{IL}-1 \beta$, and IL-4. Consistent with these observations, the levels of TNF- $\alpha, I L-1 \beta$, and IL-4 in BAL fluids of OVA-sensitized and -challenged mice were decreased by the administration of this agent. Decrease in the expression of ICAM-1 and VCAM-1 proteins may be due to the reduced TNF- $\alpha, \mathrm{IL}-1 \beta$, and IL-4 levels in the lungs. Hence, these results strongly indicate that COMPAng1 modulates inflammatory cell migration by reducing ICAM-1 and VCAM-1 expression and possibly also by suppressing TNF- $\alpha$, IL-1 $\beta$, and IL-4 expression.

The Ang1 structure consists of a carboxy-terminal fibrinogen-like domain that is responsible for Tie2 receptor binding, a central coiled-coil domain that oligomerizes these fibrinogen-like domains, and a short amino-terminal domain that superclusters these oligomers into variably-sized multimers. To achieve Tie2 receptor oligomerization and activation, Ang1 uses a modular and multimeric structure unlike that of any other known growth factor. COMP-Ang1 consists of a coiled-coil domain of COMP and a carboxy-terminal fibrinogen-like domain of Ang1. Therefore, COMP-Ang1 acts like Ang1 in binding and activation of Tie2. However, recent reports suggest that an aminoterminal domain of Ang1 may have different func- 
tions (Carlson et al., 2001; Dallabrida et al., 2005). In this regard, the action of Ang1 could be different from action of COMP-Ang1. In the present study, we have shown that COMP-Ang1 reduced bronchial inflammation, Th2 cytokines, adhesion molecules, chemokines, and airway hyper-responsiveness in a murine model of allergic airway disease. These findings suggest that the vasculartargeting agent, COMP-Ang1, can be used as an anti-inflammatory agent to treat allergic airway disease.

We conclude that administration of COMP-Ang1 reduces increased vascular permeability, Th2 cytokine levels in the lungs, inflammatory cell activation and its migration into airways, and consequent airway hyper-responsiveness to methacholine in OVA-inhaled mice. Accordingly, an Ang1 variant, COMP-Ang1 could be used as a therapeutic agent in allergic airway diseases including asthma.

\section{Acknowledgements}

We thank professor Mie-Jae Im for critical readings of the manuscript. This work was supported by Korea Research Foundation Grant funded by Korea Government (MOEHRD, Basic Research Promotion Fund) (KRF-2005201-E00014), by a grant of the Korea Health 21 R\&D project, Ministry of Health and Welfare, Republic of Korea (A060169), by a grant of the Korea Science and Engineering Foundation (KOSEF) through the National Research Lab. Program funded by the Ministry of Science and Technology [R0A-2005-000-10052-0(2007)], and also by a grant from the Korea Health 21 R\&D Project (0412CR03-0704-0001).

\section{References}

Bousquet J, Jeffery PK, Busse WW, Johnson M, Vignola AM. Asthma. From bronchoconstriction to airways inflammation and remodeling. Am J Respir Crit Care Med 2000;161: 1720-45

Carlson TR, Feng Y, Maisonpierre PC, Mrksich M, Morla AO. Direct cell adhesion to the angiopoietins mediated by integrins. J Biol Chem 2001;276:26516-25

Chae JK, Kim I, Lim ST, Chung MJ, Kim WH, Kim HG, Ko JK, Koh GY. Coadministration of angiopoietin-1 and vascular endothelial growth factor enhances collateral vascularization. Arterioscler Thromb Vasc Biol 2000;20:2573-8

Cho CH, Kammerer RA, Lee HJ, Steinmetz MO, Ryu YS, Lee $\mathrm{SH}$, Yasunaga K, Kim KT, Kim L, Choi HH, Kim W, Kim SH, Park SK, Lee GM, Koh GY. COMP-Ang1: a designed angiopoietin-1 variant with nonleaky angiogenic activity. Proc Natl Acad Sci USA 2004a;101:5547-52

Cho CH, Kammerer RA, Lee HJ, Yasunaga K, Kim KT, Choi
HH, Kim W, Kim SH, Park SK, Lee GM, Koh GY. Designed angiopoietin-1 variant, COMP-Ang1, protects against radiation-induced endothelial cell apoptosis. Proc Natl Acad Sci USA 2004b;101:5553-8

Cocks BG, de Waal Malefyt R, Galizzi JP, de Vries JE, Aversa G. IL-13 induces proliferation and differentiation of human B cells activated by the CD40 ligand. Int Immunol 1993;5: 657-63

Dabbagh K, Takeyama K, Lee HM, Ueki IF, Lausier JA, Nadel JA. IL-4 induces mucin gene expression and goblet cell metaplasia in vitro and in vivo. J Immunol 1999;162:6233-7

Dallabrida SM, Ismail N, Oberle JR, Himes BE, Rupnick MA. Angiopoietin-1 promotes cardiac and skeletal myocyte survival through integrins. Circ Res 2005;96:e8-24

Dustin ML, Rothlein R, Bhan AK, Dinarello CA, Springer TA. Induction by IL 1 and interferon-gamma: tissue distribution, biochemistry, and function of a natural adherence molecule (ICAM-1). J Immunol 1986;137:245-54

Feistritzer C, Mosheimer BA, Sturn DH, Bijuklic K, Patsch JR, Wiedermann CJ. Expression and function of the angiopoietin receptor Tie-2 in human eosinophils. J Allergy Clin Immunol 2004;114:1077-84

Foster PS, Hogan SP, Ramsay AJ, Matthaei KI, Young IG. Interleukin 5 deficiency abolishes eosinophilia, airways hyperreactivity, and lung damage in a mouse asthma model. J Exp Med 1996;183:195-201

Foster WM, Langenback EG, Bergofsky EH. Lung mucociliary function in man: interdependence of bronchial and tracheal mucus transport velocities with lung clearance in bronchial asthma and healthy subjects. Ann Occup Hyg 1982;26:227-44

Hirata N, Kohrogi H, Iwagoe H, Goto E, Hamamoto J, Fujii $\mathrm{K}$, Yamaquchi T, Kawano O, Ando M. Allergen exposure induces the expression of endothelial adhesion molecules in passively sensitized human bronchus: time course and the role of cytokines. Am J Respir Cell Mol Biol 1998;18:12-20

Hoshino M, Nakamura Y, Hamid QA. Gene expression of vascular endothelial growth factor and its receptors and angiogenesis in bronchial asthma. J Allergy Clin Immunol 2001;107:1034-8

Hwang SJ, Choi HH, Kim KT, Hong HJ, Koh GY, Lee GM. Expression and purification of recombinant human angiopoietin-2 produced in Chinese hamster ovary cells. Protein Expr Purif 2005;39:175-83

Ikeda RK, Nayar J, Cho JY, Miller M, Rodriguez M, Raz E, Broide DH. Resolution of airway inflammation following ovalbumin inhalation: comparison of ISS DNA and corticosteroids. Am J Respir Cell Mol Biol 2003;28:655-63

Jones N, Iljin K, Dumont DJ, Alitalo K. Tie receptors: new modulators of angiogenic and lymphangiogenic responses. Nat Rev Mol Cell Biol 2001;2:257-67

Kim I, Moon SO, Park SK, Chae SW, Koh GY. Angiopoietin-1 reduces VEGF-stimulated leukocyte adhesion to endothelial cells by reducing ICAM-1, VCAM-1, and E-selectin expression. Circ Res 2001;89:477-9 
Kwak YG, Song CH, Yi HK, Hwang PH, Kim JS, Lee KS, Lee YC. Involvement of PTEN in airway hyperresponsiveness and inflammation in bronchial asthma. J Clin Invest 2003; 111:1083-92

Lee KS, Kim SR, Park HS, Jin GY, Lee YC. Cysteinyl leukotriene receptor antagonist regulates vascular permeability by reducing vascular endothelial growth factor expression. J Allergy Clin Immunol 2004;114:1093-9

Lee KS, Min KH, Kim SR, Park SJ, Park HS, Jin GY, Lee YC. Vascular endothelial growth factor modulates matrix metalloproteinase-9 expression in asthma. Am J Respir Crit Care Med 2006;174:161-70

Lee YC, Lee HK. Vascular endothelial growth factor in patients with acute asthma. J Allergy Clin Immunol 2001;107: 1106

Lee YC, Kwak YG, Song $\mathrm{CH}$. Contribution of vascular endothelial growth factor to airway hyperresponsiveness and inflammation in a murine model of toluene diisocyanate-induced asthma. J Immunol 2002;168:3595-600

Lemieux C, Maliba R, Favier J, Theoret JF, Merhi Y, Sirois MG. Angiopoietins can directly activate endothelial cells and neutrophils to promote proinflammatory responses. Blood 2005;105:1523-30

Montefort S, Holgate ST. Adhesion molecules and their role in inflammation. Respir Med 1991;85:91-9

Moser R, Fehr J, Bruijnzeel PL. IL-4 controls the selective endothelium-driven transmigration of eosinophils from allergic individuals. J Immunol 1992;149:1432-8

Osborn L, Hession C, Tizard R, Vassallo C, Luhowskyj S Chi-Rosso G, Lobb R. Direct expression cloning of vascular cell adhesion molecule 1, a cytokine-induced endothelial protein that binds to lymphocytes. Cell 1989;59:1203-11

Pawankar R, Okuda M, Yssel H, Okumura K, Ra C. Nasal mast cells in perennial allergic rhinitics exhibit increased expression of the Fc epsilonRI, CD40L, IL-4, and IL-13, and can induce IgE synthesis in B cells. J Clin Invest 1997;99: $1492-9$

Persson CG. Epithelial cells: barrier functions and sheddingrestitution mechanisms. Am J Respir Crit Care Med 1996; 153:S9-10
Pizurki L, Zhou Z, Glynos K, Roussos C, Papapetropoulos A. Angiopoietin-1 inhibits endothelial permeability, neutrophil adherence and IL-8 production. Br J Pharmacol 2003; 139:329-36

Sato TN, Qin Y, Kozak CA, Audus KL. Tie-1 and tie-2 define another class of putative receptor tyrosine kinase genes expressed in early embryonic vascular system. Proc Natl Acad Sci USA 1993:90:9355-8

Seder RA, Paul WE, Davis MM, Fazekas de St Groth B. The presence of interleukin 4 during in vitro priming determines the lymphokine-producing potential of CD4+ T cells from T cell receptor transgenic mice. J Exp Med 1992;176:1091-8

Suri C, Jones PF, Patan S, Bartunkova S, Maisonpierre PC Davis S, Sato TN, Yancopoulos GD. Requisite role of angiopoietin-1, a ligand for the TIE2 receptor, during embryonic angiogenesis. Cell 1996;87:1171-80

Takakura N, Watanabe T, Suenobu S, Yamada Y, Noda T, Ito Y, Satake M, Suda T. A role for hematopoietic stem cells in promoting angiogenesis. Cell 2000;102:199-209

Thurston G, Rudge JS, loffe E, Zhou H, Ross L, Croll SD, Glazer N, Holash J, McDonald DM, Yancopoulos GD. Angiopoietin-1 protects the adult vasculature against plasma leakage. Nat Med 2000;6:460-3

Tournoy KG, Kips JC, Schou C, Pauwels RA. Airway eosinophilia is not a requirement for allergen-induced airway hyperresponsiveness. Clin Exp Allergy 2000;30:79-85

Van de Graaf EA, Out TA, Roos CM, Jansen HM. Respiratory membrane permeability and bronchial hyperreactivity in patients with stable asthma. Effects of therapy with inhaled steroids. Am Rev Respir Dis 1991;143:362-8

Wegner CD, Gundel RH, Reilly P, Haynes N, Letts LG, Rothlein R. Intercellular adhesion molecule-1 (ICAM-1) in the pathogenesis of asthma. Science 1990;247:456-9

Witzenbichler B, Westermann D, Knueppel S, Schultheiss HP, Tschope C. Protective role of angiopoietin- 1 in endotoxic shock. Circulation 2005;111:97-105

Yancopoulos GD, Davis S, Gale NW, Rudge JS, Wiegand SJ, Holash J. Vascular-specific growth factors and blood vessel formation. Nature 2000;407:242-8 